\title{
Clinical presentation of autoimmune disorders in pregnancy
}

\author{
Neha Singhal, Alka S. Gupta, Madhva Prasad* \\ Department of Obstetrics and Gynecology, Seth GS Medical College and KEM Hospital, Parel, Mumbai, Maharashtra,
} India

Received: 20 September 2017

Accepted: 27 October 2017

\section{* Correspondence:}

Dr. Madhva Prasad,

E-mail: madhva@gmail.com

Copyright: () the author(s), publisher and licensee Medip Academy. This is an open-access article distributed under the terms of the Creative Commons Attribution Non-Commercial License, which permits unrestricted non-commercial use, distribution, and reproduction in any medium, provided the original work is properly cited.

\begin{abstract}
Background: Autoimmune disorders have a significant impact over the health of an individual. This heterogenous group of disorders affects pregnancy in a multitude of ways. Pregnancies with autoimmune disorders are usually cared for by a multidisciplinary team of doctors.

Methods: Pregnancies with autoimmune disorders were studied over a one-year period in one unit of a medical college teaching hospital set up. Obstetric and neonatal outcomes were studied.

Results: Ten patients were studied. Average age was 29.9 years. Majority presented in early second trimester. Eight patients were ANA positive. Two patients had antiphospholipid antibody syndrome, for whom low molecular weight heparin was helpful. Hypothyroidism was seen in two patients. Bad obstetric history was seen in most patients. Successful neonatal outcome was seen in six patients. One patient had Evans syndrome. There were no maternal mortalities. There was one perinatal mortality.

Conclusions: Autoimmune disorders in pregnancy when managed in a tertiary care centre with multidisciplinary approach can result in good obstetric and neonatal outcomes.
\end{abstract}

Keywords: ANA positivity, Aspirin, Autoimmune disorders, Heparin, Pregnancy

\section{INTRODUCTION}

In pre-eclampsia, the prevalence of autoimmune disorders in the general population is around $3 \%$ to $7 \%$. The prevalence of this group of disorders is probably underestimated and is more common in females. ${ }^{1}$

Systemic lupus erythematosus has various manifestations, the pathognomonic investigation being ANA positivity. In the context of pregnancies with autoimmune disorders, ANA positivity is a common feature.

Many of these patients are otherwise asymptomatic apart from abortions or pregnancy associated hypertension. Few patients have more than one auto-antibody positive. Moreover, the occurrence of Antiphospholipid antibody syndrome in SLE is also well described. In the Indian context, Singh et al have described a $25.3 \%$ prevalence of APS in SLE. They have also described the increased morbidity that these women experience and the high disease burden associated with the autoimmune disorders in pregnancy. ${ }^{2}$ An analysis of ten cases of autoimmune disorders in pregnancy and discussion of various features is attempted below.

\section{METHODS}

A prospective observational study was conducted in a single unit in the department of obstetrics and gynaecology in a tertiary care hospital. All patients who were diagnosed cases of autoimmune disorders and underwent medical care, antenatal and care and delivery in the department were studied. 
The study was conducted over one year. The case files were studied and details of medical and obstetric outcomes were studied (March 2016 to February 2017). All medical outcomes such as time of onset of disease, medications which the patient was on, need for admission and any medical complications were noted. Maternal and foetal outcomes including gestational age at delivery, birth weights, problems during labour and neonatal outcomes were studied in detail.

\section{RESULTS}

The number of patients who delivered in the study period was 1056 . During this period, 10 patients of autoimmune diseases were managed. The details of the patients are presented here.

\section{Case 1}

A 30 year old married woman for 4 years G3A2 registered in our outpatient department at 20 weeks of gestation. Evaluation for bad obstetric history revealed IgM ACLA positive status. She was started on low molecular weight heparin $0.6 \mathrm{cc}$ subcutaneous twice a day and tablet Aspirin $150 \mathrm{mg}$ once a day. She required one admission at 33 weeks of gestation in view of threatened preterm labour. She was given injectable steroids and tocolytics till completion of steroids. At 37 weeks of gestation pre-induction ripening of cervix by Foley's catheter was done and she delivered vaginally a female child of $2.882 \mathrm{~kg}$ with Apgar score of 9/10.

\section{Case 2}

A 35 year old married woman for 17 years G2A1 presented at 6 weeks of gestation with bleeding per vaginum. Blood pressure was $200 / 120 \mathrm{~mm} \mathrm{Hg}$ with no albuminuria. Investigations showed anti-SSA antibody positivity and ANA positivity. Rheumatology reference was taken and she was started on once a day tablets of dexamethasone $4 \mathrm{mg}$, HCQS $200 \mathrm{mg}$ and aspirin $75 \mathrm{mg}$. Tablets Alpha methyldopa $250 \mathrm{mg}$ thrice a day and Nifedipine $10 \mathrm{mg}$ twice a day were started for blood pressure control. IgM HSV was positive (which had been performed few days prior to initial presentation of to our hospital) for which she was started on tablet acyclovir $200 \mathrm{mg}$ twice a day.

At 36 weeks of gestation she complained of generalised itching and alkaline phosphatase was found to be elevated. There was marginal improvement with ursodeoxycholic acid $300 \mathrm{mg}$ twice a day.

Serial antenatal ultrasonography showed appropriate for gestational age with an estimated birth weight of $2.4 \mathrm{~kg}$ prior to induction. At 38 weeks of gestation, induction of labour was done and there was no intrapartum fetal distress. Emergency lower segment caesarean section was done in view of failure of induction and she delivered female child of $1.59 \mathrm{kgs}$ with Apgar score of 2/10 and
9/10. Baby was shifted to NICU and required ventilation but expired on day 2 of life due to multi organ failure.

\section{Case 3}

A 35 year old woman married for 6 years G3P1L1A1, a known case of rheumatoid arthritis (RA factor positive) and hypothyroidism, presented at 8 weeks with threatened abortion.

Her first pregnancy was a second trimester abortion at 5 months of gestation, of which no details were available. In her second pregnancy, cervical encirclage was done at around 5 months of gestation and the pregnancy resulted in vaginal delivery of live born child at 9 months.

In the current pregnancy; she had a dichorionic diamniotic twin gestation. She was started on injectable progesterone support $500 \mathrm{mg}$ once a week. She was continued on once a day tablets of hydroxychloroquine (HCQS) $300 \mathrm{mg}$, aspirin $75 \mathrm{mg}$ and levothyroxine 25 microgram. Biochemical markers for aneuploidy were negative. At 18 weeks, ultrasonography showed cervical length of 1.6 centimetres (cms) and McDonald's cervical encirclage procedure was done. However, she came with complaints of pain in abdomen at 22 weeks of gestation. She was admitted in view of preterm labour. Tocolytic drugs were started but pregnancy could not be salvaged and she aborted fetuses of 480 and 490 grams respectively.

\section{Case 4}

A 32 year woman married for 4 years G3P2 IUFD2 registered at 12 weeks of gestation. Her previous pregnancies were intrauterine fetal demises, one at 8 months and other at 6 months of gestation, with history of high blood pressure in both. Investigations showed LA and IgG ACLA positive. Injection LMWH $0.6 \mathrm{cc}$ subcuteneous and tablet aspirin $150 \mathrm{mg}$ once a day were started. She followed up regularly and fetal surveillance was optimum. Labour was spontaneous and she progressed normally at 37 weeks and she delivered a male child of $2.8 \mathrm{kgs}$ with Apgar score of 9/10.

\section{Case 5}

A 30 year old woman married for 12 years G4P3L1NND2 known case of SLE presented at 22 weeks of gestation and was found to have anaemia with haemoglobin of $5.6 \mathrm{gm} \%$. After ruling out other causes, oral haematinics were initiated. Tablet aspirin $75 \mathrm{mg}$ once a day was continued, and rest of pregnancy was uneventful. Labour progressed spontaneously and she delivered male child of $2.9 \mathrm{kgs}$ with Apgar score of 9/10.

\section{Case 6}

A 23 year old woman married for 2 years primigravida registered at 26 weeks of gestation, and auscultation fetal 
heart sounds with doppler showed irregularity. Initial impression was fetal arrhythmia and a fetal echocardiogram was ordered and autoimmune profile was sent. Though fetal echocardiogram did not confirm fetal arrhythmia, ANA turned out to be positive in the titres of 1:320 (coarse speckled).

History was reviewed, and she did not report joint pains, photosensitivity, oral ulcers or other symptomatology of SLE. Rheumatologists advised C3, C4, 24-hour urine protein, anti SSA and anti SSB; which were all negative. She was started on aspirin $75 \mathrm{mg}$ OD. At 41 weeks of gestation, induction of labour by Foleys catheter was done. Emergency LSCS was done in view of fetal distress and she delivered male child of $2.868 \mathrm{kgs}$ with Apgar score of $9 / 10$.

\section{Case 7}

A 27 year old woman married for 5 years G2P1L1 at 29 weeks of gestation. She went to private practitioner with complaints of generalized swelling and rash over the body, oral ulcers and fever with chills for 10 days. She had been investigated prior to presentation here and had haemoglobin of $9.6 \mathrm{gm} \%$, whole blood count of 25000/ cu mm, platelet count of $28000 / \mathrm{cu} \mathrm{mm}$ and ANA positivity (1:1000 titres). She had received 2 units of single donor platelet transfusion and had been started on steroids, antibiotics, intravenous fluids, anti-histaminics, anti-malarials and then was referred here.

At admission, oral ulcers were present, rash was present over the malar area and abdominal examination showed 28 weeks gestation suggestive of IUGR. Whole blood count improved to 10,600 but platelet count dropped to $20000 / \mathrm{cu} \mathrm{mm}$. Viral markers were negative but SGOT was elevated (189 IU/ml) though SGPT was normal (31 IU/ml). CRP was elevated (19.5), dsDNA was positive, C3.C4 were within normal limits, c-ANCA and p-ANCA were negative and U1SNRNP was strong positive (+++). 24-hour urine protein was elevated $(1158 \mathrm{mg}$ ) and lipase was elevated $(10618 \mathrm{U} / \mathrm{ml})$. Serum TSH was $5.47 \mathrm{U} / \mathrm{ml}$. The clinical impression was one of mixed connective tissue disorder with autoimmune haemolytic anaemia with thrombocytopenia, autoimmune pancreatitis, thyroditis and nephropathy.

Haematology reference was taken and she was started on tablet prednisolone $1 \mathrm{mg} / \mathrm{kg}$, tablet azathioprine $50 \mathrm{mg}$ OD. It was further advised to give intravenous immunoglobulin or 6 units of random donor platelets (RDP) or 1 SDP transfusion; if patient goes into labour or bleeding from any site. She was also started on tablet HCQS $200 \mathrm{mg}$ twice a day. She went into inevitable preterm labour at 34 weeks of gestation and delivered a female child $1.13 \mathrm{~kg}$ with Apgar score of 9/10. Baby was shifted to NICU in view of low birth weight. 6 units RDP transfusion and one whole blood transfusion were given to the mother peripartum.
Rest of postnatal course was uneventful, and steroids were tapered. Platelet counts improved and proteinuria normalised. Neonate was discharged after 10 days of NICU stay.

\section{Case 8}

A 31 year old woman married for 12 years with a precious pregnancy G2IUFD1 complaining of bleeding per vaginum for 2 months for which she required 4 admissions between 8 to 14 weeks of gestation. Ultrasonography was done which was suggestive of single live intrauterine gestation of 15.6 weeks with no evidence of retroplacental clot and she was started on injectable progesterone support weekly, injection tranexemic acid, and injectable antibiotics and was discharged after 6 days. She again complained of bleeding at 19 weeks of gestation and was referred here in view of bleeding per vaginum and ultrasonography was suggestive of a cervical canal hematoma of 7.2x4.6 cms.

At the time of admission, uterus corresponded to 22 weeks size, on per speculum there were no lesions on cervix, minimal bleeding was present and on per vaginum examination os was closed. Investigations showed ANA positivity in the titres of 1:60. She was started on injection tranexemic acid, weekly progesterone support $500 \mathrm{mg}$, aspirin $75 \mathrm{mg}$ but she aborted at 23 weeks of gestation male child of 430 grams.

\section{Case 9}

A 31 year old woman married for 8 years G3P1L1A1registered at 13 weeks of gestation. She was diagnosed with multiple connective tissue disease one year prior to conception when she complained of joint pain, malar rash and photosensitivity. She was ANA positive and U1 SNRNP strong positive; while RA, antids DNA, anti-SSA, anti-SSB, APLA, anti-Beta2 glycoprotein were all negative. She was on prednisolone, HCQS $300 \mathrm{mg}$ OD and aspirin $75 \mathrm{mg}$ once a day. Patient was also a known case of hypothyroidism on levothyroxine 100microgram OD. Conception was spontaneous and antenatal care was regular. Preinduction ripening of the cervix with foleys catheter WAS done at 40 weeks of gestation. Labour was covered with intravenous hydrocortisone. She delivered male child of $3.174 \mathrm{~kg}$ with Apgar score of 9/10.

\section{Case 10}

A 25 year old woman married for 5 years G2A1 with 2 months of gestation, recently detected to be pregnant by a positive urine pregnancy test, presented with spotting per vaginum. Ultrasonography showed missed abortion of 8 weeks for which suction and evacuation was needed. Investigations showed ANA positive status in the titres of $1: 160(+4)$, and patient is being followed up for further evaluation. 
Table 1: Brief summary of the cases.

\begin{tabular}{|c|c|c|c|c|c|c|c|}
\hline Age & $\begin{array}{l}\text { Weeks at } \\
\text { diagnosis }\end{array}$ & $\begin{array}{l}\text { Previous } \\
\text { poor } \\
\text { obstetric } \\
\text { outcome }\end{array}$ & $\begin{array}{l}\text { Autoimmune } \\
\text { disorder }\end{array}$ & $\begin{array}{l}\text { Medical } \\
\text { disorders }\end{array}$ & Treatment & Obstetric & $\begin{array}{l}\text { Fetal } \\
\text { outcome }\end{array}$ \\
\hline 30 & 20 & Yes & IgM-aCLA + & None & $\begin{array}{l}\text { Inj. LMWH } \\
\text { Tab. aspirin }\end{array}$ & Preterm labour & Good \\
\hline 35 & 6 & Yes & $\begin{array}{l}\text { Anti-SSA + } \\
\text { ANA + }\end{array}$ & $\begin{array}{l}\text { Hypertension, } \\
\mathrm{HSV}+\end{array}$ & $\begin{array}{l}\text { T. dexa- } \\
\text { methasone } \\
\text { T. HCQS } \\
\text { T. aspirin }\end{array}$ & $\begin{array}{l}\text { Cholestatis of } \\
\text { pregnancy } \\
\text { Induction of labour }\end{array}$ & Poor \\
\hline 35 & 8 & Yes & $\mathrm{ANA}+$ & Hypothyrodism & $\begin{array}{l}\text { T. HCQS } \\
\text { Tab. Aspirin } \\
\text { T. levo-thyroxine }\end{array}$ & $\begin{array}{l}\text { Encirclage done } \\
\text { Preterm labour }\end{array}$ & Poor \\
\hline 32 & 12 & Yes & $\mathrm{LA}+\mathrm{aCLA}+$ & None & $\begin{array}{l}\text { Inj. LMWH } \\
\text { Tab Aspirin }\end{array}$ & None & Good \\
\hline 30 & 22 & Yes & ANA + & Anaemia & Tab. Aspirin & None & Good \\
\hline 23 & 26 & No & ANA + & None & Tab aspirin & $\begin{array}{l}\text { Induction of } \\
\text { labour }\end{array}$ & Good \\
\hline 27 & 29 & No & $\begin{array}{l}\text { ANA + } \\
\text { U1SNRNP + }\end{array}$ & $\begin{array}{l}\text { Autoimmune } \\
\text { haemolytic } \\
\text { anemia, } \\
\text { Evans syndrome }\end{array}$ & $\begin{array}{l}\text { T. prednisolone } \\
\text { T. azathioprine } \\
\text { T. HCQS }\end{array}$ & Preterm delivery & Good \\
\hline 31 & 8 & Yes & $\mathrm{ANA}+$ & None & T. aspirin & Preterm delivery & Poor \\
\hline 31 & 13 & Yes & $\begin{array}{l}\text { ANA + } \\
\text { U1SNRNP+ }\end{array}$ & Hypothyroidism & $\begin{array}{l}\text { T. prednisolone } \\
\text { T. HCQS } \\
\text { T. aspirin } \\
\text { T. levo-thyroxine }\end{array}$ & $\begin{array}{l}\text { Induction of } \\
\text { labour }\end{array}$ & Good \\
\hline 25 & 8 & Yes & ANA+ & None & No medication & Abortion & Poor \\
\hline
\end{tabular}

\section{DISCUSSION}

The age range of our patients ranged from 23 to 35 , with an average age of 29.9 years. The high mean age of presentation of patients with autoimmune disorders has been described in western literature and in similar settings by Kothari et al also. 3,4

Fertility was poor in this group of patients studied, evidence by an average of married life to be around 7.5 years. Autoimmune oophoritis, drug induced ovarian dysfunction and disturbance of hypothalamo-pituitary axis due to chronic inflammatory state are all postulated as reasons for poor fertility outcomes in patients with autoimmune disorders. ${ }^{5}$

Though commonly used, NSAIDs should be avoided in early gestation due to a possible low risk of miscarriage and congenital malformations. HCQS, azathioprine, cyclosporine, tacrolimus and steroids are all considered to be safe in pregnancy. ${ }^{6}$

ANA positivity was seen in 8 patients. However, while in 5 patients it was the only autoimmune abnormality, there were other associated antibodies positive in the remaining three cases. Eight patients had a prior poor obstetric outcome (either abortion or still birth or neonatal death). It is now well established that the occurrence of miscarriage is much higher in patients with autoimmune disorders. ${ }^{7,8}$

Surprisingly, associated medical disorders were not common. Two patients had hypothyroidism and one patient had hypertension. These two medical disorders are reported to be more common in pregnancies with autoimmune disorders than without. ${ }^{9}$ Three patients were on oral steroid medications throughout the pregnancy. Steroids have been reported to improve the rate of live births in some studies. ${ }^{10}$ Four patients were on HCQS throughout the pregnancy. Though HCQS is given during pregnancy with SLE, there are suggestions that it may be used successfully in pregnancies with antiphospholipid antibody syndrome also. ${ }^{11}$ Eight patients were on aspirin throughout the pregnancy. The use of low dose aspirin is well established in patients with autoimmune disorders, and is recommended by the EULAR (EUropean League Against Rheumatism). ${ }^{12}$

One patient had cholestasis of pregnancy. It is to be noted that there are upcoming hypotheses to state that cholestasis of pregnancy may be a risk factor for future autoimmune disorders. ${ }^{13}$ One patient had a flare during pregnancy and required multiple medical interventions to 
ensure maternal survival (case 7). Occurrence of flare is considered to be one of the most important predictors of poor maternal and neonatal outcomes. ${ }^{14}$ Similar to what Tan et al had observed, this patient also presented as an autoimmune haemolytic anemia. ${ }^{15}$

Four patients had preterm delivery. Though we did not use any method to predict preterm delivery, Clowse et al have shown that apart from disease activity, biochemical markers like ferritin and uric acid can also predict premature birth. ${ }^{7}$

One of the patients had been detected to have fetal heart rate abnormality in the antenatal period. But on follow, it was found to have resolved and neonatal echocardiography showed no abnormality. However, it is now well established that congenital heart defects are higher among children born to women with autoimmune disorders. $^{16}$

One patient had SLE + Evans syndrome (case 7), and though she had a difficult clinical course, there was maternal and neonatal survival. As recent as 2015, Nause et al had reported the first ever case of successful management of coexisting SLE and Evans syndrome. Our patient (case 7) is probably the second such case. ${ }^{17}$

Long term follow-up data of children born to autoimmune mothers should be maintained in developing countries like India, because it has now been recently demonstrated that a slightly increased risk of autism spectrum disorders exists. ${ }^{18}$ Overall good neonatal outcome was seen in $60 \%$ of patients. Galappathy et al have reported an approximately $45 \%$ live birth rate in similar settings. ${ }^{19}$

Appropriate contraceptive methods had been advised to all patients to avoid unwanted pregnancy, especially to prevent any possible deterioration of maternal condition due to the medical disorder.

\section{CONCLUSION}

To conclude, autoimmune disorders in pregnancy when managed in a tertiary care centre with multidisciplinary approach can result in good obstetric and neonatal outcomes.

\section{Funding: No funding sources}

Conflict of interest: None declared

Ethical approval: Not required

\section{REFERENCES}

1. Cooper GS, Bynum MLK, Somers EC. Recent insights in the epidemiology of autoimmune diseases: improved prevalence estimates and understanding of clustering of diseases. J Autoimmun. 2009;33(3-4):197-207.
2. Singh NK, Agrawal A, Singh MN, Kumar V, Godhra M, Gupta A et al. Prevalence and pattern of antiphospholipid antibody syndrome in a hospital based longitudinal study of 193 patients of systemic lupus erythematosus. J Assoc Physicians India. 2013 Sep;61(9):623-6.

3. Chakravarty EF, Nelson L, Krishnan E. Obstetric hospitalizations in the United States for women with systemic lupus erythematosus and rheumatoid arthritis. Arthritis Rheum. 2006 Mar;54(3):899-907.

4. Kothari R, Digole A, Kamat S, Nandanwar YS, Gokhale Y. Reproductive Health in Systemic Lupus Erythematosus, An experience from Government Hospital in Western India. J Assoc Physicians India. 2016 Dec;64(12):16-20.

5. Oktem O, Guzel Y, Aksoy S, Aydin E, Urman B. Ovarian function and reproductive outcomes of female patients with systemic lupus erythematosus and the strategies to preserve their fertility. Obstet Gynecol Surv. 2015 Mar;70(3):196-210.

6. Jones A, Giles I. Fertility and pregnancy in systemic lupus erythematosus. Indian $\mathrm{J}$ Rheumatol. 2016;11Suppl S2:128-34.

7. Clowse MEB, Wallace DJ, Weisman M, James A, Criscione-Schreiber LG, Pisetsky DS. Predictors of preterm birth in patients with mild systemic lupus erythematosus. Ann Rheum Dis. 2013 Sep;72(9):1536-9.

8. Sakthiswary R, Rajalingam S, Norazman MR, Hussein H. Antinuclear antibodies predict a higher number of pregnancy loss in unexplained recurrent pregnancy loss. Clin Ter [Internet]. 2017;166(2):e98101 .

9. Arkema EV, Palmsten K, Sjöwall C, Svenungsson E, Salmon JE, Simard JF. What to expect when expecting with systemic lupus erythematosus (SLE): a population-based study of maternal and fetal outcomes in SLE and Pre-SLE. Arthritis Care Res (Hoboken). 2016 Jul;68(7):988-94.

10. Al Arfaj A, Khalil N. Pregnancy outcome in 396 pregnancies in patients with SLE in Saudi Arabia. Lupus. 2010 Dec;19(14):1665-73.

11. Sciascia S, Hunt BJ, Talavera-Garcia E, Lliso G, Khamashta MA, Cuadrado MJ. The impact of hydroxychloroquine treatment on pregnancy outcome in women with antiphospholipid antibodies. Am J Obstet Gynecol. 2016;214(2):273.e1-273.e8.

12. Andreoli L, Bertsias GK, Agmon-Levin N, Brown S, Cervera R, Costedoat-Chalumeau N, et al. EULAR recommendations for women's health and the management of family planning, assisted reproduction, pregnancy and menopause in patients with systemic lupus erythematosus and/or antiphospholipid syndrome. Ann Rheum Dis. 2017 Mar; 76(3):476-85.

13. Erlinger S. Intrahepatic cholestasis of pregnancy: A risk factor for cancer, autoimmune and cardiovascular diseases? Clin Res Hepatol Gastroenterol. 2016 Apr; 40(2):139-40. 
14. Surita FG de C, Parpinelli MA, Yonehara E, Krupa F, Cecatti JG. Systemic lupus erythematosus and pregnancy: clinical evolution, maternal and perinatal outcomes and placental findings. Sao Paulo Med J. 2007 Mar;125(2):91-5.

15. Tan LK, Tan HK, Lee CT, Tan ASA. Outcome of pregnancy in Asian women with systemic lupus erythematosus: experience of a single perinatal centre in Singapore. Ann Acad Med Singapore. 2002 May;31(3):290-5.

16. Vinet E, Pineau CA, Scott S, Clarke AE, Platt RW, Bernatsky S. Increased congenital heart defects in children born to women with systemic lupus erythematosus: results from the offspring of systemic lupus erythematosus mothers registry study. Circulation. 2015 Jan;131(2):149-56.

17. Nause S, Spiegler J, Weichert J, Hartge D. Therapeutic management of evans syndrome in a pregnancy with maternal systemic lupus erythematosus. Z Geburtshilfe Neonatol. 2015 Jun;219(4):190-2.

18. Vinet É, Pineau CA, Clarke AE, Scott S, Fombonne É, Joseph L, et al. Increased Risk of Autism Spectrum Disorders in Children Born to Women With Systemic Lupus Erythematosus: Results From a Large Population-Based Cohort. Arthritis Rheumatol. 2015 Dec;67(12):3201-8.

19. Galappatthy P, Jayasinghe JDD, Paththinige SC, Sheriff RMH, Wijayaratne LS. Pregnancy outcomes and contraceptive use in patients with systemic lupus Erythematosus, rheumatoid arthritis and women without a chronic illness: a comparative study. Int J Rheum Dis. 2017 Jun;20(6):746-54.

Cite this article as: Singhal N, Gupta AS, Prasad M. Clinical presentation of autoimmune disorders in pregnancy. Int J Reprod Contracept Obstet Gynecol 2017;6:5401-6. 